\title{
Bioinformatics Approaches for Improvement of Biohydrogen Production: A Review
}

\author{
Muhammad Jawed, Wang Jun, Pi Jian, Xu Li, and Yunjun Yan
}

\begin{abstract}
Hydrogen $\left(\mathrm{H}_{2}\right)$ production from biomass is considered as the main source of renewable energy, is a characteristic feature of prokaryotes. $\mathrm{H}_{2}$ is believed as the cleanest fuel without evolution of greenhouse gases on combustion. The main biological processes for $\mathrm{H}_{2}$ production are: biophotolysis of water by algae and cyanobacteria, dark fermentation and photo-fermentation. Since last decades, a lot of work has been carried out for understanding and refining bio-hydrogen production and still it has to overcome some of the serious limitations so that it becomes a viable proposal. The bottlenecks include thermodynamic inefficiency, trouble in using lignocellulosics as feedstock, cost of raw material and low $\mathrm{H}_{2}$ molar yields (HMY). To get rid of these major problems, the conventional approach is inadequate and people has to dynamically think modern bioinformatics approaches to overcome these factors. The accessibility of enormous sequenced genomes, functional genomic studies, and the progress of in-silico models at the genome level, metabolic pathway reconstruction, and synthetic biology tactics predict engineering strategies to enhance $\mathrm{H}_{2}$ production in an organism. This review examines the current status and progressions that have been made in the area of biotechnology and bioinformatics, to understand and enhance $\mathrm{H}_{2}$ evolution to overcome current limitations and make $\mathrm{H}_{2}$ production from biological means, a reality in the coming future.
\end{abstract}

Index Terms-Biohydrogen, in-silico metabolic engineering, functional genomics, synthetic biology.

\section{INTRODUCTION}

Studies on the feasibility and viable production of renewable fuels from biological means as an alternative to fossil fuels has enhanced in recent years and additionally have been increased further by various ecological problems related with fossil fuels, such as greenhouse gas emission, global warming and higher price level hikes with an unstable supply. Biological Hydrogen Production (BHP) plays a vital role since it is supposed as the sparkling fuel with no emission of greenhouse gases on combustion [1].

Apart from wet lab experiments, in silico approaches, functional genomics, metabolic modifications on genomic level and flux balance analysis can be used to improve the hydrogen $\left(\mathrm{H}_{2}\right)$ producing abilities [2]. In silico models at genomic level provide a powerful resource for logical engineering of biological systems for improvement in BHP [3], [4]. A precise genome-scale model of an organism helps

Manuscript received April 22, 2016; revised July 1, 2016.

The authors are with the Key Laboratory of Molecular Biophysics, the Ministry of Education, Huazhong University of Science and Technology, Wuhan 430074, PR China (e-mail: Dr_jawed@ hust.edu.cn, yanyunjun@hust.edu.cn, 1018497090@qq.com, xuli@hust.edu.cn, yanyunjun@hust.edu.cn). us in studying the effect of environmental and genetic limitations on it, and hence these facts motivate experiments in the area of metabolic engineering. Ever since the development of the first genome scale model in Haemophilus influenzae [5], the obtainable high-throughput biological data have been utilized professionally for structures level modeling approaches. The construction and modeling of biological components, functions and organisms non-existing in nature or redesigning present biological organizations to perform novel functions is termed as Synthetic biology [6]. In this review, we discuss the utilization of bioinformatics approaches and techniques to improve $\mathrm{H}_{2}$ production to overcome the current difficulties (Fig. 1).

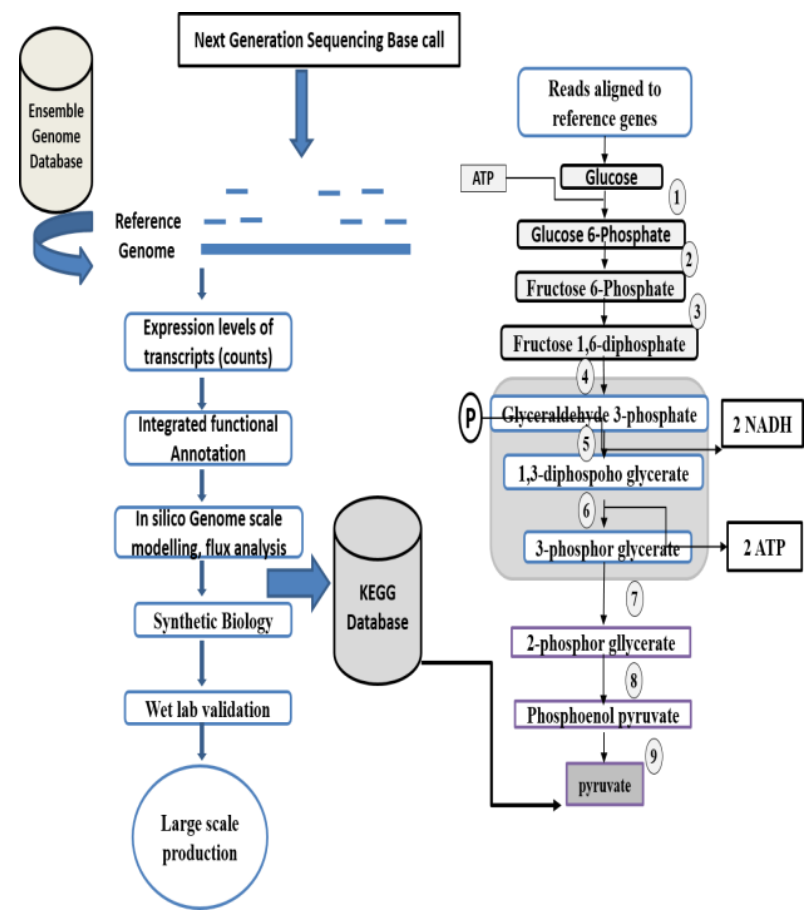

Fig. 1. Scheme represents various approaches for enhancement of $\mathrm{H}_{2}$ production.

\section{MEthODS FOR BIOHYDROGEN PRODUCTION}

For $\mathrm{H}_{2}$ production from biomass, direct or indirect bio-photolysis, photo-fermentation and dark-fermentation methods are often used. Photo-autotrophic microorganisms like cyanobacteria or green microalgae used the method of bio-photolysis that possess chlorophyll A and other pigments and has a capacity to capture sunlight and split water to make $\mathrm{H}_{2}$. Even though, there are some barriers in this method such as: the $\mathrm{O}_{2}$ evolved during this method suppresses the activation of hydrogenase subunits, gas mixture formed during the process is combustible, low photosynthetic conversion efficiencies and large surface area requirement 
[7].

Design of reactor is one of the most important features of $\mathrm{H}_{2}$ production from dark fermentation. In the meantime, increasing the partial pressures of $\mathrm{H}_{2}$ during fermentation affects the process performance. Various strategies have been reported to reduce $\mathrm{H}_{2}$ partial pressure, among which gas sparging and vacuum application are widely used. Although, it is essential to establish an effective method for $\mathrm{H}_{2}$ production and gain electric energy through fuel cells.

\section{HydRogEN PRODUCTION FROM OtHER RENEWABLE ENERGY SOURCES}

The performance examination of $\mathrm{H}_{2}$ production from other renewable sources have been investigated in many studies. Solar energy has been found to be the most inexhaustible; $\mathrm{H}_{2}$ production from solar energy is considered to be the decisive solution for sustainable energy. Solar energy is also used for the technology of splitting water and can be divided into the four main categories: photochemical systems; semiconductor systems; photo biological systems; and hybrid and other systems [8].

\section{LIMITATIONS AND IMPORTANT BARRIERS TO $\mathrm{H}_{2}$ AND BIOHYDROGEN PRODUCTION}

The main limitations in the development of $\mathrm{H}_{2}$ production processes include economic and technological barriers. Economic barriers incorporate the cost of $\mathrm{H}_{2}$ production and distribution, expenditure of components and materials, and competition with the fossil fuels, while technological limitations include issues like $\mathrm{H}_{2}$ storage, compressor and distribution networks, absence of strong fuel cell technologies, and incorporation with the existing infrastructure.

\section{VARIOUS APPROACHES FOR IMPROVING $\mathrm{H}_{2}$ PRODUCTION}

\section{A. Next Generation Sequencing: Application in \\ Bio-hydrogen Production}

The exact order of nucleotides exist in any DNA or RNA molecule is determined by the method of nucleic acid sequencing. The demand for cheaper and faster sequencing methods has augmented significantly after the completion of the first human genome sequence, which led to the development of next-generation sequencing (NGS). NGS platforms allows the sequencing of millions of fragments of DNA from a single sample, which facilitates an entire genome to be sequenced in less than one day [9].

The full benefit of NGS will not be achieved until extremely high performance computing and intensive bioinformatics support are able to interpret and utilize raw sequence data. A variety of software tools for NGS data analysis (Table I) are available online e.g. 1) alignment of reads to a reference sequence; 2) de novo assembly; 3 ) reference-based assembly; 4) base-calling and/or genetic variation detection (such as SNV, Indel); 5) genome annotation; and 6) utilities for data analysis. NGS appears to have almost boundless applications in the field of life sciences including $\mathrm{H}_{2}$ and biodiesel production. The whole-genome shotgun project of C. perfringens strain JJC containing its assembly and annotation has been deposited at DDBJ/EMBL/GenBank under the accession no. AWRZ00000000 for further applications [10].

\begin{tabular}{|c|c|c|}
\hline Tools & Description & Web links \\
\hline $\begin{array}{l}\text { FASTQC } \\
\text { Toolkit }\end{array}$ & $\begin{array}{l}\text { A quality control application } \\
\text { for high throughput sequence } \\
\text { data. }\end{array}$ & $\begin{array}{l}\text { http://www.bioinfor } \\
\text { matics.babraham.ac } \\
\text {.uk/projects/ fastqc/ }\end{array}$ \\
\hline $\begin{array}{l}\text { NGS QC } \\
\text { Toolkit }\end{array}$ & $\begin{array}{l}\text { A toolkit for the quality } \\
\text { control of NGS data. }\end{array}$ & $\begin{array}{l}\text { http://www.nipgr.re } \\
\text { s.in/ngsqctoolkit.ht } \\
\mathrm{ml}\end{array}$ \\
\hline Velvet & De novo Genome Assembly. & $\begin{array}{l}\text { http://www.ebi.ac.u } \\
\text { k/zerbino/velvet/ }\end{array}$ \\
\hline ALLPATHS & De novo Genome Assembly. & $\begin{array}{l}\text { http://www.broadin } \\
\text { stitute.org/software/ } \\
\text { allpaths-lg/ blog/ }\end{array}$ \\
\hline SOAPdenovo & De novo Genome Assembly. & $\begin{array}{l}\text { http://soap.genomic } \\
\text { s.org.cn/soapdenov } \\
\text { o.html }\end{array}$ \\
\hline SSAKE & $\begin{array}{l}\text { De novo Genome } \\
\text { assembler for short } \\
\text { DNA sequence reads. }\end{array}$ & $\begin{array}{l}\text { http://www.bcgsc.c } \\
\text { a/platform/bioinfo/s } \\
\text { oftware/ssake }\end{array}$ \\
\hline Maq & $\begin{array}{l}\text { Mapping and assembly with } \\
\text { qualities. }\end{array}$ & $\begin{array}{l}\text { http://maq.sourcefor } \\
\text { ge.net/ }\end{array}$ \\
\hline BWA & $\begin{array}{l}\text { Burrows-wheeler alignment } \\
\text { tool. }\end{array}$ & $\begin{array}{l}\text { http://bio-bwa.sourc } \\
\text { eforge.net/bwa.shtm } \\
1\end{array}$ \\
\hline SSAHA & $\begin{array}{l}\text { Sequence Search and } \\
\text { Alignment by Hashing } \\
\text { Algorithm. }\end{array}$ & $\begin{array}{l}\text { https://www.sanger. } \\
\text { ac.uk/resources/soft } \\
\text { ware/ssaha/ }\end{array}$ \\
\hline Scripture & $\begin{array}{l}\text { Method for transcriptome } \\
\text { reconstruction that relies } \\
\text { solely on RNA-Seq reads. }\end{array}$ & $\begin{array}{l}\text { http://www.broadin } \\
\text { stitute.org/software/ } \\
\text { scripture/ }\end{array}$ \\
\hline Cufflinks & $\begin{array}{l}\text { Transcriptome assembly and } \\
\text { differential expression } \\
\text { analysis for RNA-Seq. }\end{array}$ & $\begin{array}{l}\text { http://cole-trapnell-1 } \\
\text { ab.github.io/cufflin } \\
\text { ks/ }\end{array}$ \\
\hline TopHat & $\begin{array}{l}\text { Fast splice junction mapper } \\
\text { for RNA-Seq reads. }\end{array}$ & $\begin{array}{l}\text { http://ccb.jhu.edu/s } \\
\text { oftware/tophat/inde } \\
\text { x.shtml }\end{array}$ \\
\hline SpliceMap & $\begin{array}{l}\text { De novo splice junction } \\
\text { discovery and alignment tool. }\end{array}$ & $\begin{array}{l}\text { http://web.stanford. } \\
\text { edu/group/wonglab/ } \\
\text { SpliceMap/ }\end{array}$ \\
\hline SISSRs & $\begin{array}{l}\text { A novel algorithm for precise } \\
\text { identification of binding sites } \\
\text { from short reads generated }\end{array}$ & $\begin{array}{l}\text { http://sissrs.rajajoth } \\
\text { i.com/ }\end{array}$ \\
\hline
\end{tabular}

Model-based analysis for ChIP-Seq.

PeakSeq A program for identifying and ranking peak regions in ChIP-Seq experiments.

CisGenome An integrated tool for tiling

COV2HTML array, ChIP-seq, genome and cis-regulatory element analysis. A visualization and analysis tool of bacterial next generation sequencing (NGS) data.

Artemis

Genome browser and annotation tool.

Ngsplot

Quick mining and visualization of next-generation sequencing data by integrating genomic databases. http://liulab.dfci.har vard.edu/MACS/

http://info.gersteinla b.org/PeakSeq

http://www.biostat.j hsph.edu/hji/cisgen ome/

http://www.ncbi.nl m.nih.gov/pubmed/ 24512253

http://www.sanger.a c.uk/resources/soft ware/artemis/

https://code.google. com/p/ngsplot/ 
Galaxy

Galaxy is an open source, web-based platform for data intensive biomedical research. https://usegalaxy.or g/
DNA sequence analysis depends on the development of novel transcriptome analysis approaches, but still techniques are highly dependent on available genomic sequence. Currently, NGS based transcriptomics method has been applied to species without reference genome sequences as well. To reconstruct metabolic network terpenoid biosynthesis pathway in green alga Botryococcus braunii race B [11], to investigate the triacylglyceride accumulation mechanism of the unsequenced oleaginous microalgae of Neochloris oleoabundans and Chlorella vulgaris, and to investigate the transcriptomic profiling during induction of $\mathrm{H} 2$ photo-production in the organism Chlamydomonas moewusii via RNA-Seq [12]. The innovative transcriptomic analysis technique on $C$. moewusii was reported to be the first to be applied to a potential $\mathrm{H}_{2}$ producing green alga. In another study, transcriptomic, metabolite and proteomic analyses were carried out in the $\mathrm{H}_{2}$-producing bacterium Clostridium butyricum to investigate the changes at the molecular level that occur when the metabolism shifts to $\mathrm{H}_{2}$ production [13].

\section{B. Functional Genomics}

The main objective of functional genomics is to study the gene/protein functions and interactions at the genome level. The enormous generation of genomic data from the NGS platforms in the recent years is responsible for the accumulation of genome information in databases (Fig. 2).

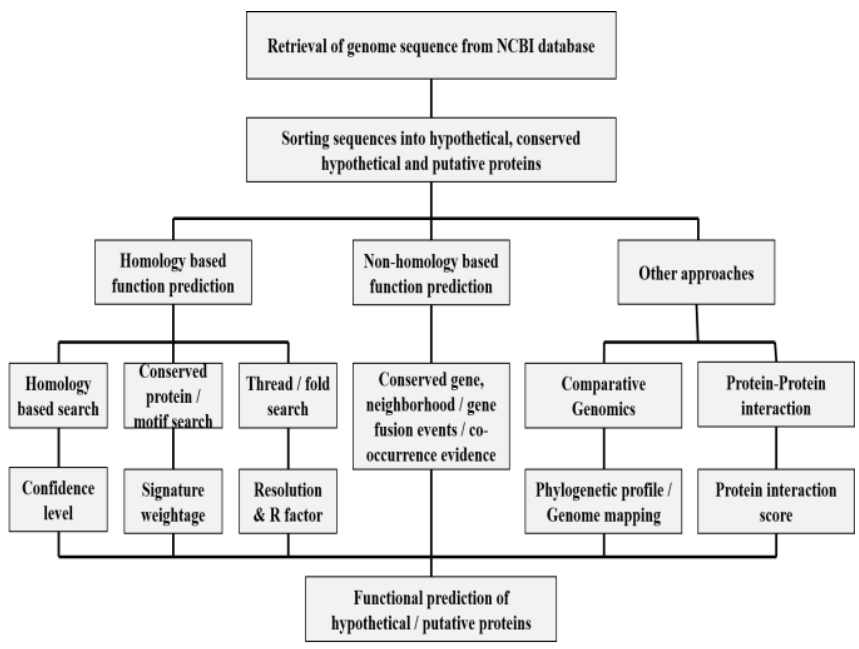

Fig. 2. Scheme characterizes integrated annotation / re-annotation strategy used for functional assignment of complete genome of organisms.

This creates a significant move towards gathering gene information through comparative genomics, proteomics, metabolomics and in particular, functional genomics [14].

"Dynamic biological data fusion method" was used to re-annotate the complete proteome of $E$. coli $\mathrm{K}-12$, for enhanced $\mathrm{H}_{2}$ production. About $29 \%$ of the protein sequences previously annotated as imaginary have now been assigned with clear/known functions. Furthermore, the updated functional information is publicly available as a database, "REC-DB" (http://recdb.bioinfo.aukbc.org.in/recdb/) [15].
The growing oil price and environmental concerns have transformed our interest in utilizing biomass for the production of biofuel. Though, it is essential to develop high performance microbes that are capable of producing biofuels with very high efficiency in order to compete with the fossil fuel (Fig. 3). Microbes, capable of producing different biofuels including bioethanol, biobutanol, alkane, biodiesel, and $\mathrm{H}_{2}$ have been successfully developed by using methods such as systems metabolic engineering [16].

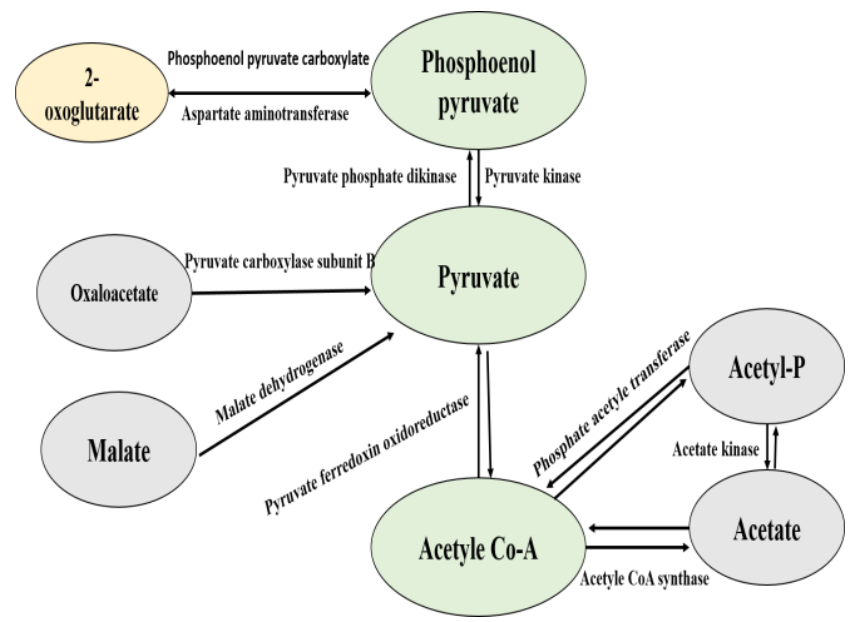

Fig. 3. Scheme demonstrates the reconstructed pyruvate metabolism pathway of $C$. hydrogenoformans. The conversion of Phosphoenol pyruvate to oxaloacetate and conversion of oxaloacetate to 2-oxoglutarate catalyzed by phosphoenolpyruvate carboxylase and aspartate aminotransferase respectively have been newly included in the pathway [12].

Likewise, metabolic flux analysis and in-silico metabolic models study for increased $\mathrm{H}_{2}$ production are available for a number of $\mathrm{H}_{2}$ producers. Several organism based pathway databases such as Cyclone, MediCyc and PathCase [17], are available that assimilates functional genomics and metabolic pathway information. Despite the presence of several databases with gene and metabolic pathway information, the pathway, metabolite and enzyme data of complete gene sets are unrevealed [18].

\section{Synthetic Biology Approach}

Synthetic biology is the engineering of biological molecules in the deliberate redesign and construction of innovative biological systems and organisms that does not exist in nature to perform new functions for useful purposes. Table II shows list of tools used for functional prediction and Table III shows tools used for pathway reconstruction and flux balance analysis. Another potential route for biological $\mathrm{H}_{2}$ production is the conversion of biomass into formate, which can subsequently be processed into $\mathrm{H}_{2}$ by $E$. coli., formate is also a widely used commodity chemical [19].

TABLE II: LIST OF TOOLS FOR FUNCTION PREDICTION

\begin{tabular}{lll}
\hline \hline $\begin{array}{l}\text { Function } \\
\text { prediction } \\
\text { tools }\end{array}$ & Prediction method & Web links \\
\hline BLAST & Similarity based search. & http://www.ncbi.nl \\
& & m.nih.gov/blast/Bl \\
& & ast.cgi \\
CDD & Conserved proteins domain & http://www.ncbi.nl \\
& classification. & m.nih.gov/Structur \\
& & e/cdd/cdd. \\
& & shtml
\end{tabular}


InterProScan Protein domain search.

\begin{tabular}{|c|c|c|}
\hline String & $\begin{array}{l}\text { Known and predicted protein } \\
\text { interaction. }\end{array}$ & $\begin{array}{l}\text { http://string.embl. } \\
\mathrm{de} /\end{array}$ \\
\hline Pfam & Conserved region search. & $\begin{array}{l}\text { http://pfam.xfam.o } \\
\mathrm{rg} /\end{array}$ \\
\hline ProtFun & $\mathrm{Ab}$ initio function prediction. & $\begin{array}{l}\text { http://www.cbs.dt } \\
\text { u.dk/services/Prot } \\
\text { Fun/ }\end{array}$ \\
\hline PFP tool & $\begin{array}{l}\text { Automated protein function } \\
\text { prediction. }\end{array}$ & $\begin{array}{l}\text { http://kiharalab.or } \\
\text { g/web/pfp.php }\end{array}$ \\
\hline ScanProsite & Pattern and profile search. & $\begin{array}{l}\text { http://prosite.expa } \\
\text { sy.org/scanprosite/ }\end{array}$ \\
\hline PPSearch & Protein motifs search. & $\begin{array}{l}\text { http://www.ebi.ac. } \\
\text { uk/Tools/ppsearch } \\
\text { / }\end{array}$ \\
\hline CombFunc & $\begin{array}{l}\text { GO based function prediction } \\
\text { server. }\end{array}$ & $\begin{array}{l}\text { http://www.sbg.bi } \\
\text { o.ic.ac.uk/mwass/c } \\
\text { ombfunc/ }\end{array}$ \\
\hline I-TASSER & $\begin{array}{l}\text { Protein structure and function } \\
\text { predictions. }\end{array}$ & $\begin{array}{l}\text { http://zhanglab.cc } \\
\text { mb.med.umich.ed } \\
\text { u/I-TASSER/ }\end{array}$ \\
\hline PSORTb 3.0 & $\begin{array}{l}\text { Subcellular localization (SCL) } \\
\text { based predictor. }\end{array}$ & $\begin{array}{l}\text { http://www.psort.o } \\
\mathrm{rg} / \mathrm{psortb} / \text { index.ht } \\
\mathrm{ml}\end{array}$ \\
\hline AutoFACT & $\begin{array}{l}\text { Automated protein function } \\
\text { prediction. }\end{array}$ & $\begin{array}{l}\text { http://megasun.bc } \\
\text { h.umontreal.ca/Sof } \\
\text { tware/Auto }\end{array}$ \\
\hline ConFunc & $\begin{array}{l}\text { Gene Ontology based protein } \\
\text { function prediction. }\end{array}$ & $\begin{array}{l}\text { FACT.htm } \\
\text { http://www.sbg.bi } \\
\text { o.ic.ac.uk/confunc }\end{array}$ \\
\hline ProFunc & $\begin{array}{l}\text { Prediction of protein function } \\
\text { from 3D structure. }\end{array}$ & $\begin{array}{l}\text { http://www.ebi.ac. } \\
\text { uk/thornton-srv/da } \\
\text { tabases/ profunc/ }\end{array}$ \\
\hline SVMProt & $\begin{array}{l}\text { Web-based support vector } \\
\text { machine software for functional } \\
\text { classification of a protein from its } \\
\text { primary sequence. }\end{array}$ & $\begin{array}{l}\text { http://jing.cz3.nus. } \\
\text { edu.sg/cgi-bin/sv } \\
\text { mprot.cgi }\end{array}$ \\
\hline
\end{tabular}

TABLE III: LIST OF TOOLS FOR PATHWAY RECONSTRUCTION AND FLUX BALANCE ANALYSIS

\begin{tabular}{|c|c|c|}
\hline Tools & Description & Web links \\
\hline MetRxn & $\begin{array}{l}\text { To integrate genome-scale } \\
\text { metabolic network } \\
\text { reconstructions. }\end{array}$ & $\begin{array}{l}\text { http://www.metrxn. } \\
\text { che.psu.edu/ }\end{array}$ \\
\hline GraphViz & $\begin{array}{l}\text { Interaction network visualization } \\
\text { software tools. }\end{array}$ & $\begin{array}{l}\text { http://www.graphvi } \\
\text { z.org/ }\end{array}$ \\
\hline Systrip & $\begin{array}{l}\text { Interaction network visualization } \\
\text { software tools.. }\end{array}$ & $\begin{array}{l}\text { http://tulip.labri.fr/T } \\
\text { ulipDrupal/?q1/4systr } \\
\text { ip }\end{array}$ \\
\hline Cytoscape & $\begin{array}{l}\text { Interaction network visualization } \\
\text { software tools }\end{array}$ & $\begin{array}{l}\text { http://www.cytosca } \\
\text { pe.org/ }\end{array}$ \\
\hline $\begin{array}{l}\text { CyTargetLi } \\
\text { nker }\end{array}$ & $\begin{array}{l}\text { To integrate different regulatory } \\
\text { interactions into their network } \\
\text { analysis approaches. }\end{array}$ & $\begin{array}{l}\text { http://projects.bigca } \\
\text { t.unimaas.nl/cytarge } \\
\text { tlinker }\end{array}$ \\
\hline GLAMM & $\begin{array}{l}\text { Reaction network visualization } \\
\text { tools that incorporate experimental } \\
\text { data. }\end{array}$ & $\begin{array}{l}\text { http://glamm.lbl.go } \\
\text { v/ }\end{array}$ \\
\hline Vanted & $\begin{array}{l}\text { Reaction network visualization } \\
\text { tools that incorporate experimental } \\
\text { data. }\end{array}$ & $\begin{array}{l}\text { http://vanted.ipk-ga } \\
\text { tersleben.de/ }\end{array}$ \\
\hline $\begin{array}{l}\text { NUPACK, } \\
\text { Vienna }\end{array}$ & $\begin{array}{l}\text { RNA structure design and } \\
\text { prediction. }\end{array}$ & $\begin{array}{l}\text { http://www.nupack. } \\
\text { org/ }\end{array}$ \\
\hline $\begin{array}{l}\text { RNA Web } \\
\text { suite } \\
\text { PathFinder }\end{array}$ & $\begin{array}{l}\text { Tool for the dynamic visualization } \\
\text { of metabolic pathways based on } \\
\text { annotation data. }\end{array}$ & $\begin{array}{l}\text { http://bibiserv.techf } \\
\text { ak.uni-bielefeld.de/ } \\
\text { pathfinder/ }\end{array}$ \\
\hline CARMEN & $\begin{array}{l}\text { Performs in silico reconstruction } \\
\text { of metabolic networks to interpret } \\
\text { genome data in a functional } \\
\text { context. }\end{array}$ & $\begin{array}{l}\text { http://carmen.cebite } \\
\text { c.uni-bielefeld.de/c } \\
\text { gi-bin/index. }\end{array}$ \\
\hline
\end{tabular}

MetNetMa Used for the reconstruction of the ker metabolic networks.

CellNetAna Constraint-based flux analysis tool lyzer used in network visualization.

Omix

OpenFlux

A network visualization tool that is particularly good for visualizing fluxes. analysis tools while using a GUI (Graphical User Interface).

FiatFlux Performs local flux ratio analysis to determine relative fluxes at branch points.

COBRA

Flux-balance analysis and flux distribution calculation.

Systems

Biology

Research

Tool http://www.tomfort h.co.uk/metnetmake r/

http://www2.mpima gdeburg.mpg.de/pro jects/cna/ cna.html http://www.omix-vi sualization.com/\#st hash. hQJZSx7S.dpbs

http://openflux.sour ceforge.net/

http://www.imsb.et hz.ch/research/zam boni/resour ces/fiatflux.html http://opencobra.git hub.io/

http://www.ieu.uzh ch/wagner/software/ SBRT/

\section{CONCLUSION}

In the recent years, substantial research on $\mathrm{H}_{2}$ producing organisms, have given visions into their metabolism and physiological properties. Before using an organism for $\mathrm{H}_{2}$ production process on industrial level, there is a need to overcome many challenges. The present review demonstrates that the mainstream of the present challenges can be minimize by a combination of different methods using bioinformatics and biotechnology approaches starting from reactor designs to synthetic biology. Nevertheless, more research devotion is needed to implement these approaches as a vital tactic for the development of microorganisms for large scale applications on industrial level. In silico metabolic engineering at genome-scale and use of synthetic biology are especially likely to be at the front of these developments. Hence, it is possible to achieve approximately $10 \mathrm{~mol} \mathrm{H}_{2}$ per mol of glucose for industrialization by using the versatile bioinformatics approaches trailed by wet lab validation in the near future.

\section{CONFLICT OF INTEREST}

The authors declare no conflict of interest.

\section{REFERENCES}

[1] G. Lazzerini, S. Lucchetti, and F. P. Nicese, "Green House Gases (GHG) emissions from the ornamental plant nursery industry: A life cycle assessment (LCA) approach in a nursery district in central Italy," Journal of Cleaner Production, 2016, vol. 112, Part 5, pp. 4022-4030.

[2] S. Y. Zhou et al., "In-silico design of a new energetic material-1-Amino-5-nitrotetrazole with high energy and density," Computational Materials Science, 2016, vol. 112, pp. 67-74.

[3] J. Mathews and G. Wang, "Metabolic pathway engineering for enhanced biohydrogen production," International Journal of Hydrogen Energy, 2009, vol. 34, no. 17, pp. 7404-7416.

[4] M. Jawed et al., "Enhanced H production and redirected metabolic flux via overexpression of fhlA and pncB in Klebsiella HQ-3 strain," Appl Biochem Biotechnol, 2015. 
[5] D. J. Morton et al., "The heme-binding protein (HbpA) of Haemophilus influenzae as a virulence determinant," International Journal of Medical Microbiology, 2009, vol. 299, no. 7, pp. 479-488.

[6] D. Jullesson et al., "Impact of synthetic biology and metabolic engineering on industrial production of fine chemicals," Biotechnology Advances, 2015, vol. 33, no. 7, pp. 1395-1402.

[7] J. Wang et al., "Effects of increasing the NAD $(\mathrm{H})$ pool on hydrogen production and metabolic flux distribution in Enterobacter aerogenes mutants," International Journal of Hydrogen Energy, 2013, vol. 38, no. 30, pp. 13204-13215.

[8] H. Ahmad et al., "Hydrogen from photo-catalytic water splitting process: A review," Renewable and Sustainable Energy Reviews, 2015 vol. 43, pp. 599-610.

[9] M. Datto and R. L. Lundblad, "DNA, RNA chemical properties (including sequencing and next-generation sequencing)," Encyclopedia of Cell Biology, 2016, Academic Press: Waltham, pp. 24-35.

[10] K. A. Hassan et al., "Genomic analyses of clostridium perfringens isolates from five toxinotypes," Research in Microbiology, 2015, vol. 166, no. 4, pp. 255-263.

[11] Z. Xu et al., "Nitrogen deprivation-induced de novo transcriptomic profiling of the oleaginous green alga Botryococcus braunii 779," Genomics Data, 2015, vol. 6, pp. 231-233.

[12] G. R. Kumar and N. Chowdhary, "Biotechnological and bioinformatics approaches for augmentation of biohydrogen production: A review," Renewable and Sustainable Energy Reviews, 2016, vol. 56, pp. 1194-1206.

[13] C. Li et al., "Complete genome sequence of Clostridium butyricum JKY6D1 isolated from the pit mud of a Chinese flavor liquor-making factory," Journal of Biotechnology, 2016, vol. 220, pp. 23-24.

[14] M. Fernández-Escobar et al., "Use of functional genomics to understand replication deficient poxvirus-host interactions," Virus Research, 2016, vol. 216, pp. 1-15.

[15] K. V. Solomon et al., "Extracting data from the muck: deriving biological insight from complex microbial communities and non-model organisms with next generation sequencing," Current Opinion in Biotechnology, 2014, vol. 28, pp. 103-110.

[16] J. M. Park, T. Y. Kim, and S. Y. Lee, "Constraints-based genome-scale metabolic simulation for systems metabolic engineering," Biotechnology Advances, 2009, vol. 27, no. 6, pp. 979-988.
[17] M. A. Nik et al., "A comparative study of metamodeling methods for the design optimization of variable stiffness composites," Composite Structures, 2014, vol. 107, pp. 494-501.

[18] E. Kirtay, "Recent advances in production of hydrogen from biomass," Energy Conversion and Management, 2011, vol. 52, no. 4, pp. 1778-1789.

[19] A. V. Puga, "Photocatalytic production of hydrogen from biomass-derived feedstocks," Coordination Chemistry Reviews, 2016, vol. 315, pp. 1-66.

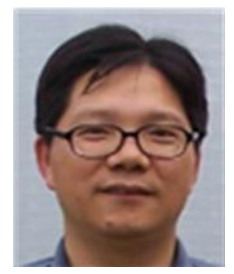

Yan Yunjun was born at Luotian county, Hubei Province, China, in September 1969. He got the B.S. in biology, Central China Normal University, Wuhan city. He got the M.S. in zoology, Central China Norma University, Wuhan City in 1993. He got the Ph.D. in hydrobiology, Institute of Hydrobiology, the Chinese Academy of Sciences, Wuhan City, China in 1995. He was professor of biotechnology and from 1998 to2002. $\mathrm{He}$ is the vice dean of College of Life Sciences and Technology, College of Life Sciences and Technology, Huazhong University of Science and Technology; 1037, Luoyu Road, Hongshan District, Wuhan 430074, China from 2012 still now. Prof. Yan is senior committee member of the Chinese Society of Biological Engineering and Chinese Society of Microbiology. He holds a Second-grade Award from China Medical Association in 2009, and from Journal "Chinese Journal of Biotechnology" in 2009 and 2011.

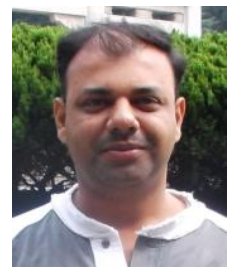

Muhammad Jawed was born in August 1977, obtained the master's degree in biotechnology from Karachi University, Pakistan. He worked as a medical technologist in the Aga Khan University and hospital, which is the premier institute of medical research in Pakistan (2005 - 2007). He was appointed as a research officer in Liaquat University of Medical and Health Sciences, Pakistan, and worked intensively on real time PCR and DNA sequence analyzer for different projects related to viral hepatitis and genetic disorders in Humans (2008 - 2013). Currently he is doing research as a Ph.D. candidate in the field of biochemistry and molecular biology, in Huazhong University of Science and Technology, Wuhan, P.R. China (Sept. 2013 - July 2016) 